This is a pre-copyedited, author-produced version of an article by Colin Mackie (University of Leeds) and Malcolm M. Combe (University of Aberdeen) which was published online by the Journal of Environmental Law on 27 July 2018 at https://doi.org/10.1093/jel/eqy019.

\title{
CHARGES ON LAND FOR ENVIRONMENTAL LIABILITIES: A MATTER OF 'PRIORITY' FOR SCOTLAND
}

\author{
Colin Mackie* \\ Malcolm M. Combe**
}

\begin{abstract}
This article examines the viability and utility of introducing a statutory power in Scotland enabling its environmental regulators to take a first-ranking charge over land. It would facilitate recovery of costs incurred in undertaking the unfulfilled environmental obligations of a recalcitrant or financially distressed operator. Such a charge has been characterised as contrary to Scots land law. The article makes two original contributions, the latter of which is pertinent to other jurisdictions considering implementing such a charge. First, Scots land law is found to be receptive to such a charge provided there is appropriate publicity and its priority as compared to other charges created in favour of third parties at an earlier date is expressly stated in statute. Second, with the policy rationales for the 'polluter-pays' principle of EU environmental law used as a frame through which to understand the multi-faceted functions of corporate environmental liability, such a charge is shown to play an important role in facilitating these. Recommendations are made for its implementation in statute.
\end{abstract}




\section{Introduction}

This article examines the viability and utility of introducing a statutory power in Scotland enabling its environmental regulators to take a first-ranking charge (or security) ${ }^{1}$ over an operator's heritable ${ }^{2}$ property. It would arise under frameworks of environmental liability, with the charge securing costs incurred by a regulator, including accrued interest, where it undertook works associated with the operator's unfulfilled environmental obligations. ${ }^{3}$

The power is best illustrated with an example. Consider a situation where chemicals spill from containers at an industrial site, migrating to and affecting adjacent premises. Following site investigation, the incident is found to have caused environmental damage to land under the applicable legal framework. Where the regulator undertook the requisite remediation works because the operator was either unwilling to carry them out itself timeously or was financially unable to do so, the power would enable the regulator to take a charge over heritable property owned by the operator in respect of the costs incurred, including accrued interest. If the sum secured remained unpaid, the regulator's power of sale under the charge could be exercised to realise the asset and recover the debt.

\footnotetext{
* Lecturer in Business Law, School of Law, University of Leeds (c.mackie@leeds.ac.uk)

** Senior Lecturer, School of Law, University of Aberdeen (m.m.combe@abdn.ac.uk)

${ }^{1}$ In this article, the term 'charge' is preferred to 'security'. Whilst 'security' is the correct Scots law term for a subordinate real right in someone else's property, English law terminology has come to be used in Scotland in some situations, such as in relation to the charging order that can be constituted in certain circumstances by local authorities: see text accompanying nn 36-42. This article will use 'charge' throughout, deferring to comparative ease and those circumstances in Scotland where the terminology of charge prevails.

${ }^{2}$ The 'heritable' terminology stems from the law of succession. It is also sometimes known as 'immoveable property' or 'land'.

${ }^{3}$ It could secure costs associated with two categories of environmental obligations: first, preventing and/or remediating environmental damage; second, obligations under a permit, licence or other authorisation to restore the environment following the termination of an activity or the closure of a facility (eg a mine or landfill). In this article, the term 'environmental liabilities' will refer to both.
} 
Such a power is conferred under frameworks of environmental liability applicable in England and Wales. ${ }^{4}$ It is also present in Singapore ${ }^{5}$ and parts of Australia. ${ }^{6}$ A comparable power is not, however, available under equivalent frameworks in Scotland meaning that its regulators, specifically the Scottish Environment Protection Agency (SEPA) and local authorities, cannot benefit from it. ${ }^{7}$ The perception, one enunciated forcefully during debates in the UK Parliament during the mid-1990s, is that the charge is contrary to prevailing Scots land law. ${ }^{8}$ SEPA or a local authority could, in theory, utilise certain court actions to seek recourse from land owned by a debtor. ${ }^{9}$ But, crucially, not only are there significant time and cost implications associated with doing so, priority would not be achieved when compared with prior charges. ${ }^{10}$ Thus, in Scotland, the issue of priority and the inefficacy of current measures hinder cost recovery by environmental regulators.

This article examines whether the inapplicability of the statutory charge for environmental liabilities in Scotland could and should be altered to offer an additional enforcement tool to its regulators. That assessment comprises three distinct questions. First,

\footnotetext{
${ }^{4}$ Environmental Damage (Prevention and Remediation) (England) Regulations 2015, SI 2015/810 (as amended) (the 'English Regulations'), reg 27(1) (environmental damage in England); Environmental Damage (Prevention and Remediation) (Wales) Regulations 2009, SI 2009/995 (as amended), reg 27(1) (environmental damage in Wales); Environmental Protection Act (EPA) 1990, ss 78P(3)(a)(i) and 78P(4)(b) (contaminated land); EPA 1990, s 81A(1)(b) (statutory nuisance).

${ }^{5}$ Environmental Protection and Management Act (Ch 94A, 2002 Rev Ed) s 53(1).

${ }^{6}$ See e.g. Contaminated Land Management Act 1997 (NSW), s 40(1); Environment Protection Act 1970 (Vic), s 62(3); Environmental Management and Pollution Control Act 1994 (Tas), s 74V(1); Contaminated Sites Act 2003 (WA), s 32(2).

${ }^{7}$ In relation to the contaminated land regime, s 78P(14) EPA 1990 states that the charging provisions, 'do not extend to Scotland'. Section 81A(10) EPA 1990 Act has a similar carve out for statutory nuisance. The Regulations enacted by Scotland to implement the requirements of the Environmental Liability Directive, The Environmental Liability (Scotland) Regulations 2009, are silent on the capacity for the regulator to take a charge on premises where it has undertaken works on the operator's behalf.

${ }^{8}$ For instance, when the Environment Bill was debated in the Lords, the Earl of Lindsay stated: 'I understand that the existing conveyancing practices in Scotland do not include the use of charging notices of this kind, and that the introduction of such a system would require fundamental changes to be made to the conveyancing system.' HL Deb 7 March 1995, vol 562, col 221. This position was echoed in the Commons by Sir Paul Beresford: HC Deb 28 June 1995, vol 262, col 959.

${ }^{9}$ See text accompanying nn 29-32.

10 ibid.
} 
is Scots land law receptive to such a charge (the viability question)? Second, do the environmental protection arguments justify introduction of the power and for the charge created under it to be first-ranking (the utility question)? Third, should both questions be answered affirmatively, how could the power be legislated for (the implementation question)?

These questions have not been addressed in the literature. With limited exception, statutory charges for environmental liabilities have eluded scholarly analysis. In a brief account, Poustie doubted the veracity of the argument raised in Parliament that introduction of statutory charging provisions in Scotland would have required fundamental changes to be made to the conveyancing system. ${ }^{11}$ He cited statutory provisions which enabled a Scottish local authority to impose charges on premises in respect of works undertaken. ${ }^{12}$ However, he did not address the issue of priority. In the context of the law of England and Wales, Marks ${ }^{13}$ and Mackie and Fogleman ${ }^{14}$ examined the relative priority of the statutory charge when compared with charges granted in favour of third parties. And Mackie and Fogleman considered whether the statutory charge should be accorded priority. ${ }^{15}$ However, a normative justification for the power itself has not previously been posited nor its full regulatory potential explored. ${ }^{16}$ The three questions detailed above, the latter two being pertinent to many jurisdictions whose legal frameworks do not cater for such a power, form the overarching aims

\footnotetext{
${ }^{11}$ Mark Poustie, 'Environment' (Reissue) in Niall Whitty (ed), The Laws of Scotland: Stair Memorial Encyclopaedia (LexisNexis 2006) para 735

12 ibid.

${ }^{13}$ Jonathan Marks, 'The Environmental Liability of Lenders in England: Is the Tide Coming in' (2001) 27 N C J Int'I L \& Com Reg $1,21$.

${ }^{14}$ Colin Mackie and Valerie Fogleman, 'Self-Insuring Environmental Liabilities: A Residual Risk-Bearer's Perspective' (2016) 16 JCLS 293, 320-321.

15 ibid 321-324.

${ }^{16}$ It has been observed that there is a dearth of analysis when it comes to considering the justification for the law of security as a whole, never mind in relation to environmental law: Andrew Steven, 'Time for Cinderella to Go to the Ball?' in Susan Scott and Jeannie van Wyk (eds), Property Law Under Scrutiny (Juta 2016) 64-69. It is hoped the consideration of aspects of security here may stimulate further analysis.
} 
of this article and connect to a larger, more complex question: how can law drive more responsible and sustainable corporate conduct?

The methodology adopted in this article is specific to the research question asked. The viability question is determined through doctrinal analysis of Scots jurisprudence and analysis of the relevant statutory provisions. Comparative analysis is then made of frameworks of liability in England and in Wales which are (or their variants are) applicable in Scotland to generate clarity as to the nature and priority of the charge created by them. This enables an assessment of whether Scots land law and its legal culture is receptive to that model of charge or whether a tailored power may be needed. The policy rationales for the 'polluter-pays' principle of EU environmental law, derived from primary and secondary sources, are used to frame the utility question. Whilst connection with that literature engenders original analysis of the potential utility of the power, the authors are attuned to the methodological challenges. There are, of course, other analytical frames. Whilst, for instance, the idea of 'stewardship' is valuable and relevant, ${ }^{17}$ the 'polluter-pays' principle offers the dominant normative basis for, and policy position behind, corporate environmental liability within EU law. Though necessarily 'localised' at the EU level and specific to that legal culture, ${ }^{18}$ its theoretical and doctrinal basis is sophisticated and illuminating and can be used to understand the diverse functions of, and justifications for, the imposition of that category of liability more broadly. The charge's utility is assessed through its capacity to harness and channel those functions and so further that principle's admittedly 'localised' yet venerable policy objectives. Considering that particular methodological motivation, the planned departure of the UK from the EU (and the legal process related to that) does not affect the analysis. The implementation question is not 'answered' in the sense of specific drafting being offered. Rather, two areas of concern to the prospective utility of the charge are identified with drafting ideas proffered to address them.

\footnotetext{
${ }^{17}$ Emma Lees, 'The Polluter Pays Principle and the Remediation of the Land' (2016) 8 IJLBE 2, 3; Emma Lees, 'Interpreting the Contaminated Land Regime: Should the “Polluter” Pay?' (2012) 14 ELR 98, 107.

${ }^{18}$ Eloise Scotford, Environmental Principles and the Evolution of Environmental Law (Hart 2017) 11-12.
} 
The significance of this investigation lies in, and derives from, two regulatory trends. First, key frameworks of environmental liability applicable in Scotland do not mandate that operators make financial provision for their environmental liabilities. ${ }^{19}$ The same is true in England and Wales. Mandatory regimes do exist in some $\mathrm{EU}^{20}$ and domestic frameworks. ${ }^{21}$ Yet in the Environmental Liability Directive (the 'ELD'), ${ }^{22}$ the principal environmental liability framework in and across the $\mathrm{EU}$, there is no requirement for mandatory financial provision for liabilities arising under that regime. It is also absent in the regulations implemented by Scotland (and England and Wales) to enact the Directive's requirements into national law. There are a variety of reasons for this trend. An overriding one appears to be the perception that mandatory provision would impose additional financial burdens upon industry, particularly small and medium sized enterprises. ${ }^{23}$ Operators would be required to purchase products, such as insurance or bonds, from third parties and/or set aside reserves. Second, even where financial provision is mandated there is widespread regulatory acceptance of self-insurance across the UK. ${ }^{24}$ This is troublesome as it allows operators to satisfy mandatory financial provision requirements by merely evidencing their financial strength or that of a related company; there is no obligation to 'ring fence' funds.

\footnotetext{
${ }^{19}$ An operator (or a related party, such as a parent company) makes 'financial provision' where they provide and maintain evidence that appropriate provision exists for its environmental liabilities. This could, depending on the type of environmental obligations at hand, comprise insurance, a parent company guarantee, a bond, or a cash deposit. However, such measures are fallible. For instance, the Scottish Coal Company Ltd was liquidated in 2013 with the result that approximately $£ 73,000,000$ of restoration works was externalised following a wholly inadequate provision of a bond: Joint Liquidators of the Scottish Coal Company Limited [2013] CSOH 124 [7].

${ }^{20}$ See, eg, Directive 2006/21/EC on the management of waste from extractive industries [2006] OJ L102/15, art 14; Council Directive 1999/31/EC on the landfill of waste [1999] OJ L182/1 (the 'Landfill Directive'), art 8(a)(iv); Directive 2009/31/EC on the geological storage of carbon dioxide [2009] OJ L140/114, art 19(1).

${ }^{21}$ See, eg, the Petroleum Act 1998.

${ }^{22}$ Directive 2004/35/CE on environmental liability regarding the prevention and remedying of environmental damage [2004] OJ L143/56.

${ }^{23}$ Hubert Bocken, 'Financial Guarantees in the Environmental Liability Directive: Next Time Better' (2006) 15 EEELR 13, 18.

${ }^{24}$ Mackie and Fogleman (n 14) 298 (see Table 1 for overview).
} 
Insufficient or inappropriate financial provision exposes regulators (and so society) to the risk of operators having insufficient funds to undertake their environmental obligations. However, as we shall see, the power could be used to secure the costs incurred by the regulator should it choose to undertake the works, with both parties agreeing a payment schedule. If the financial condition of the operator deteriorated and it later succumbed to insolvency proceedings, a regulator with a charge over the operator's heritable property would have direct recourse to that asset if full payment had not been made. Were that charge firstranking, the debt secured would be recovered in its entirety if less than or equal to the net sale proceeds of the heritable property. In the absence of security, where that operator was woundup the regulator would join the other unsecured, non-preferential creditors at the 'back of the queue' for payment. ${ }^{25}$ They are likely to receive very little. ${ }^{26}$

It must be recognised from the outset that a decision to prioritise the statutory charge is a decision that a debt owed to society is to be prioritised to a debt owed to a company's creditors. In the context of a secured creditor, this is unproblematic where there is sufficient value in the heritable property to accommodate both charges. But, as we shall see, there are commercial and human rights implications for creditors whose charges, having been overreached by a regulator's charge, no longer secure the entire debt owed to them. And the regulator's charge would deplete the pool of assets available to unsecured creditors upon the company's entry into insolvency proceedings. The environmental protection arguments must, therefore, be compelling, and drafting of the power unequivocal, if these consequences are to be justifiable.

\footnotetext{
${ }^{25}$ For the ranking of unsecured non-preferential creditors in Scotland, see s 107 Insolvency Act 1986 (IA 1986) (voluntary winding up) and r 4.66(1)(c) Insolvency (Scotland) Rules 1986/1915 (compulsory winding up). For England and Wales, see s 107 IA 1986 (voluntary winding up) and r 14.12(2) Insolvency (England and Wales) Rules 2016/1024.

${ }^{26}$ Insolvency Service, 'Continuity of Essential Supplies to Insolvent Businesses, Impact Assessment' (March 2014) 6, para 22 <https://www.gov.uk/government/uploads/system/uploads/attachment data/file/328136/Annex C - Impact Assessment.doc.>
} accessed 24 June 2018. 
We argue that the viability and utility questions can be answered affirmatively and recommend that the power be implemented in frameworks of environmental liability in Scotland. On the question of viability, it is found that - contrary to established thinking - Scots land law is receptive to such charges provided there is appropriate publicity and the priority of the charge as compared to those created in favour of third parties at an earlier date is set out expressly in statute. On the question of utility, the power is demonstrated to have an important role to play in fulfilment of the 'first order' policy rationales for the 'polluter-pays' principle of EU environmental law - fairness, cost internalisation and desire to avoid distortions in trade. Certain 'second order' policy rationales are identified which centre on generating more responsible and sustainable corporate conduct through influencing consumer preferences, each of which may be facilitated by the power. Neither set of rationales may be fulfilled to the same extent by the cost recovery mechanisms currently available to environmental regulators in Scotland. On the implementation question, we identify the priority and scope of a charge to be crucial to its utility and offer recommendations as to how these could be catered for by a legislator.

Whilst the three questions posed in this article are necessarily narrow, much of the analysis is pertinent to other jurisdictions. Where the power is not a feature of a framework of environmental liability within a given jurisdiction, the environmental protection arguments evidence the merits of implementing the power, particularly where that jurisdiction is experiencing similar regulatory trends as the UK regarding financial provision. Even where such a power is a feature, the arguments developed here make clear that the legislation may need to be revised if it is to be deployed so as to fulfil its regulatory potential.

This article is structured as follows. Section 2 will examine whether Scots land law is receptive to the introduction of such a charge (the viability question). Section 3 will consider whether the environmental protection arguments justify introduction of the power and for the charge created under it to be first-ranking (the utility question). Section 4 will offer recommendations as to how such a charge could be catered for in statute and specific drafting issues to consider (the implementation question). Section 5 will draw conclusions. 


\section{The Viability Question}

This section considers how Scots law operates in relation to the constitution of security rights in land, testing its receptivity to the introduction of the statutory charge. As a preliminary point, there is nothing to stop the owner of land in Scotland granting a standard security for environmental liabilities in terms of the Conveyancing and Feudal Reform (Scotland) Act 1970 (the '1970 Act'). As we shall see, that Act introduced the standard security as the primary voluntary charge over land in Scots law. Such a charge would secure an (environmental) obligation to pay money or indeed an obligation to do something. There is something of a precedent for this, from when Scottish council housing was susceptible to a tenant's right to buy at a reduced rate. ${ }^{27}$ Councils insisted on imposing clawback standard securities to secure any uplift in value obtained by the new owners through a quick sale of the property within a defined period. That being the case, such standard securities would be subject to the standard ranking rules (ie prioritised by reference to time of registration) unless a ranking agreement could be agreed with a prior creditor. ${ }^{28}$ Plus, the essentially voluntary nature of such a charging arrangement would make it part of the negotiation mix of any deal as opposed to a tool that environmental regulators could rely on (and perhaps shift the balance of power in a negotiation).

A regulator could also make use of the Scots diligence ${ }^{29}$ processes of inhibition and adjudication in relation to land, those being forms of judicial security whereby an unsecured creditor can freeze then seize land of a non-paying debtor who has capital in the form of

\footnotetext{
${ }^{27}$ This right, found in the Housing (Scotland) Act 1987, ended with the Housing (Scotland) Act 2014 (asp 14).

${ }^{28} 1970$ Act, s 19.

29 'Diligence' in this context is the term for various processes of debt enforcement in Scots law, with each process being dictated by the nature of the asset(s) owned by the debtor.
} 
heritable property via court action. ${ }^{30}$ Taking such steps, however, would not allow for an improved ranking position in relation to prior charges (as the court action would need to be completed before priority could be established), meaning they would be of limited use to a regulator when a debtor had already granted a charge over the land. Concerns had been expressed during debates in the UK Parliament, where a Scottish MP stated that the judicial security route was a, 'long, involved and expensive process' when contrasted to that provided by the statutory charge. ${ }^{31}$ This assertion is borne out by contemporary legal practice, where adjudication actions in the Court of Session are a rarity. ${ }^{32}$ The fact that obtaining judicial security is such a cumbersome process, involving the court action of adjudication and expiry of a certain time period thereafter, is, perhaps, a causative influence.

For these reasons, the alternatives beyond voluntary or judicial securities must be analysed. These devices will be considered alongside the principles that underpin them, before offering a view on the most suitable model for any environmental charging order.

\subsection{Constituting Real Rights in Land}

Many systems of property law pay heed to the publicity principle. Scots property law is no exception. ${ }^{33}$ This principle is to the effect that third parties should be able to gauge what real

\footnotetext{
${ }^{30}$ See George Gretton, The Law of Inhibition and Adjudication (2nd edn, Butterworths/Law Society of Scotland 1996). Adjudication has been prospectively abolished and replaced by a similar process called land attachment, in terms of the Bankruptcy and Diligence etc (Scotland) Act 2007 (asp 3) (BDSA 2007). The relevant provisions have never been brought into force and it can now be doubted whether they ever will be.

${ }^{31}$ HC Deb 28 June 1995, vol 262, col 957 (Mr Sam Galbraith MP). The problems with adjudication more generally were noted by the Scottish Law Commission in its Report on Diligence (Scot Law Com No 183, 2001) ch 2.

${ }^{32}$ Writing in 1996, Gretton stated adjudication was 'uncommon in current practice': Gretton (n 30) 207. In a more recent textbook, it is noted that it is 'little used': the Rt Hon Lord Eassie and Hector MacQueen (eds), Gloag and Henderson: The Law of Scotland (14th edn, W Green 2017) para 48.33.

${ }^{33}$ See generally George Gretton and Andrew Steven, Property, Trusts and Succession (3rd edn, Bloomsbury Professional 2017) paras 4.19-4.21 and paras 7.2-7.6 and Kenneth Reid, The Law of Property in Scotland (Law Society of Scotland/ Butterworths 1996) para 8.
} 
rights (including ownership or rights in security) are in existence with reference to information that is easy to discern or obtain, to allow them to organise their affairs accordingly. Whilst parties can constitute personal rights by agreement with each other (within the usual confines of contractual regulation), parties are generally unable to do that with real rights. By real rights, it is meant rights with erga omnes rather than inter partes effect. Something beyond a private bargain is normally needed for rights which are 'good against the world'. In other words, although there is freedom of contract (because only the parties are affected), there is less freedom of property (because of the impact on third parties).

Registration is both the normal and most principled way to achieve publicity for real rights in land. The transfer of ownership of heritable property must be registered in the Land Register. ${ }^{34} \mathrm{~A}$ similar rule applies in relation to securities and the only way to constitute a security over land is through a standard security, in terms of section 9 of the 1970 Act. ${ }^{35}$ At first reading, that section gives the impression no alternative securities exist for land. Further analysis reveals this to be a deceptive simplification.

Under a variety of statutory frameworks, local authorities can create charges over heritable property in their own favour in respect of particular expenses incurred by them. ${ }^{36}$ Use of such charges has been promoted by the Scottish Government in appropriate regulatory contexts. ${ }^{37}$ In line with the publicity principle, any such charging order must be publicised in the Land Register. In this regard, reference can be made to section 108 of the Civic

\footnotetext{
${ }^{34}$ Land registration in Scotland is governed by the Land Registration etc (Scotland) Act 2012 (asp 5), although earlier systems of publicity via registration date back to the seventeenth century.

${ }^{35}$ Douglas Cusine and Robert Rennie, Standard Securities (2nd edn, Lexis Nexis UK 2002).

${ }^{36}$ See Eassie and MacQueen (n 32) para 36.10. On the history and application of these devices, see William Gordon, Scottish Land Law (2nd edn, W Green 1999) paras 20-227 - 20-241.

${ }^{37}$ Guidance issued by the Scottish Government in relation to the implementation of the Housing (Scotland) Act 2006 states that, 'Local authorities should continue to issue charging orders...to recover costs where it has enforced demolition or closing orders': Scottish Government, Implementing the Housing (Scotland) Act 2006, Parts 1 and 2: Advisory Guidance for Local Authorities Volume 2 Housing Renewal Areas and Repair, Improvement and Demolition (March 2009) 82 [G.17] <http://www.gov.scot/Resource/Doc/265425/0079492.pdf> accessed 24 June 2018.
} 
Government (Scotland) Act 1982, which allows a local authority to charge land where it has incurred expense to repair a building when it was 'necessary in the interests of health or safety or to prevent damage to any property' ${ }^{38}$ or for the execution of certain works. ${ }^{39}$ Meanwhile, section 131(3) of the Housing (Scotland) Act 1987 can apply to secure sums relating to the demolition of a building, encumbering both the site of the building, 'and any yard, garden or pertinent belonging to the building or usually enjoyed therewith'. Both of these statutes then refer to a procedure in Schedule 9 of the Housing (Scotland) Act 1987 which incorporates publicity via the Land Register. Reference can also be made to similar regimes in section 172 of the Housing (Scotland) Act 2006 (asp 1) (providing a 'repayment charge' to secure expenses incurred by a local authority under that legislation) or section $4 A(5)$ of the Tenements (Scotland) Act 2004 (asp 11) (where a local authority has paid the owner's share of costs in an apartment complex in certain circumstances)..$^{40}$ There is also a charging order regime in the Building (Scotland) Act 2003 (asp 8). ${ }^{41}$ This can be used to secure 'qualifying expenses' relating to 'Compliance and Enforcement' and 'Defective and Dangerous Buildings' under that legislation. ${ }^{42}$

A company ${ }^{43}$ can also grant a floating charge over its heritable (and moveable) property. These charges are creatures of statute. ${ }^{44}$ Scots law was not initially accommodating

\footnotetext{
${ }^{38}$ In relation to the exercise of powers under section 87.

39 Under section 99.

${ }^{40}$ Tangential reference can also be made to section 23 of the Health and Social Services and Social Security Adjudications Act 1983 which provides a charging regime for local authorities that have incurred costs in providing certain accommodation services to a person

${ }^{41}$ In terms of sections 46A-46H, as introduced by the Buildings (Recovery of Expenses) (Scotland) Act 2014 (asp 13). See further David Anderson, 'Call it a Comeback' (2014) 59(10) J Law Soc Sc 34

${ }^{42}$ Publicity via registration is needed for validity: Building (Scotland) Act 2003, s 46E.

${ }^{43}$ Limited liability partnerships, building societies, co-operative societies, community benefit societies and European Economic Interest Groupings can also grant floating charges. This article will focus on UK companies.

${ }^{44}$ They first became widely available after the Companies (Floating Charges) (Scotland) Act 1961. See now Part XVIII of the Companies Act 1985 (CA 1985) and the IA 1986
} 
of them. ${ }^{45}$ That they do not need to be registered in the Land Register did not ease their reception. A system which provided for another level of publicity, through a Register of Floating Charges, has been legislated for but never brought into force. ${ }^{46}$ Some publicity is provided, however, by the registration requirement at Companies House (which requires a company to register a security within 21 days of its creation, ie the date of its delivery). ${ }^{47}$ Upon enforcement (eg appointment of a receiver) or liquidation, a floating charge has effect as if it were a 'fixed security' over the property to which it has attached. ${ }^{48}$ As noted above, the only Scots law option for such a charge in land is the standard security under the 1970 Act, so a crystallised floating charge has the effect of a standard security. A floating charge has no proprietary effect prior to attachment.

We consider that a floating charge model would not be suitable for any new Scots security in relation to environmental liabilities for several reasons. First, the very essence of a floating charge is that it subsists over the asset(s) in such a way that the granter can use and dispose of those asset(s) for normal business purposes until the occurrence of certain specified future events (eg liquidation or appointment of a receiver) ${ }^{49}$ This may render the security of little or no value when it is needed most. Secondly, the floating charge is a device sculpted to fit the granter (ie a registered corporate entity) rather than the grantee (which, in our scenario, would be the environmental regulator). A third party can be put on notice about a potential floating charge by dealing with a particular entity, allowing the relevant corporate register pertaining to such granters to be checked, but a third party could never have similar warning about who else that entity might have been dealing with. This could lead to a publicity deficit. A more fundamental publicity issue could emerge when the principles of property law

\footnotetext{
${ }^{45}$ See the remarks of Lord President Cooper in Carse v Coppen 1951 SC 233, 239.

${ }^{46}$ See the BDSA 2007 ( $n$ 30). If Part 2 of that Act is brought into force, it will repeal CA 1985, Part XVIII. This now seems unlikely. See Andrew Steven and Hamish Patrick, 'Reforming the Law of Secured Transactions in Scotland' in Louise Gullifer and Orkun Akseli (eds), Secured Transactions Law Reform: Principles, Policies and Practice (Hart 2016) 262-263.

${ }^{47}$ Companies Act 2006, s 859E(1).

${ }^{48}$ IA 1986, ss 53(7) and 54(6); CA 1985, s 463(2).

${ }^{49}$ MacMillan v T Leith Developments Ltd (in receivership and liquidation) [2017] CSIH 23 [77].
} 
are considered. Even if there was a new register created for such securities, ${ }^{50}$ to be sympathetic with Scots land law the charge would need to be publicised in the Land Register (either as a separate step to registration in another register, or by integrating any new register with the Land Register). Thirdly, the problems Scotland has already had with floating charges in terms of its land law would, at the very least, lead to scepticism of such a new device. ${ }^{51}$ Fourthly, the charging approach for contaminated land and statutory nuisance adopted in England and Wales applies in a way that makes enforcing authorities mortgagees, rather than floating chargeholders. ${ }^{52}$ That this 'fixed' approach has been adopted in England and Wales suggests Scotland would be going against the grain to do the opposite. Finally, where Scots law has provided statutory security mechanisms to local authorities for costs incurred during certain operations, the prevailing model has involved charges over identified properties, which again suggests the floating charge route is not appropriate for any new charging order.

\subsection{Statutory Charges over Land: Ranking}

The standard position in Scots law is that real rights in land (including securities) are prioritised by reference to time of registration in accordance with the maxim prior tempore potior jure. ${ }^{53}$ Statutory charges over land rank in accordance with that general rule subject to any provisions in the relevant statute,$^{54}$ meaning that special wording is needed to displace that rule. This was

\footnotetext{
50 That could, theoretically, be modelled on the Register of Floating Charges proposed in the BDSA 2007. We are not arguing for an equivalent register for environmental charges. We simply acknowledge the possibility.

51 These issues culminated in Sharp v Thomson 1997 SC (HL) 66. The Scottish Law Commission analysed that case and subsequent developments in its Report on Sharp v Thomson (Scot Law Com No 208, 2007).

${ }^{52}$ For contaminated land, s 78P4(b) EPA 1990 provides the 'enforcing authority shall... have all the same powers and remedies under the Law of Property Act 1925, and otherwise, as if it were a mortgagee by deed.... For statutory nuisance, s 81D EPA 1990 is to similar effect.

${ }^{53}$ Gretton and Steven (n 33) para 4.45. See also the Real Rights Act 1693.

${ }^{54}$ Eassie and MacQueen (n 32) para 36.10.
} 
clarified in Sowman $v$ City of Glasgow District Council, ${ }^{55}$ where the phrase 'real and preferable lien and burden', as it appeared in section 236(1) of the Glasgow Streets Sewers and Buildings Consolidation Order Confirmation Act 1937, was held not to trump a prior-ranking standard security. ${ }^{56}$ The court noted, ${ }^{57}$

Quite correctly it was not contended on behalf of the district council that the common law of Scotland accords to a right in security in land in favour of a public body any priority of ranking over the rights of heritable creditors whose rights in security in the same land became vested in them before the emergence of the right conferred upon the public body. If there is to be such priority of ranking in favour of a public body it must be conferred by statute.

The Court then explained that such a priority would have to be clear: "bearing in mind the serious consequences for prior heritable creditors of such priority of ranking, we would have expected that an intention to accord to the local authority's right in security such a special advantage would not be left to implication. ${ }^{58}$ That the priority of the statutory charge must be catered for unequivocally in the relevant statute to outrank a prior charge contrasts markedly with the position in England and Wales. The conclusion drawn by Marks ${ }^{59}$ and Mackie and Fogleman ${ }^{60}$ is that the regulator's charge would be granted priority over an earlier charge, even where the legislation conferring the power did not state so explicitly. The preeminent authority in this area is Westminster City Council v Haymarket Publishing Ltd. ${ }^{61}$ There, the Court of Appeal had to determine entitlement to a sum secured by a 'charge on the land comprised in the hereditament' created in favour of a local authority under section $17 \mathrm{~B}(3)$ of the General

\footnotetext{
551985 SLT 65

${ }^{56}$ Under s 236(1), purchasers, lenders and others acquiring rights to the lands and heritage 'for value without notice' of the charge were not affected by it unless notice of it had been registered.

57 Sowman (n 55) 66 (emphasis added).

58 ibid 67 (emphasis added). The court also considered another aspect of the interplay between different secured creditors, noting the sale of land by an enforcing standard security holder would not extinguish the right: ibid 68.

${ }^{59}$ Marks (n 13) 21.

${ }^{60}$ Mackie and Fogleman (n 14) 320-321.

${ }^{61}[1981] 1$ WLR 677 (CA)
} 
Rate Act 1967. A bank benefited from an earlier charge by way of legal mortgage over that land. Lord Denning MR reasoned that the authorities ${ }^{62}$ led 'inevitably' to the interpretation that 'a charge on the land' meant a charge on '"all the estates and interests in the land"' not just the owner's. ${ }^{63}$ Thus, the local authority's charge ranked first. ${ }^{64}$

Returning to the position in Scots law, the default rule (ie security rights prioritised by time of registration) would not prevent a suitably drafted priority mechanism in statute. For example, paragraph 4 of Schedule 9 of the Housing (Scotland) Act 1987 establishes a priority over other securities for a charging order securing expenses incurred by a local authority in relation to a house or building. Meanwhile, section $173(2)(b)$ of the Housing (Scotland) Act 2006 ranks registered repayment charges above future securities and 'all existing burdens and incumbrances on the same property' except those created pursuant to certain other enactments (including Schedule 9 of the 1987 Act). In contrast, nothing in the Buildings (Scotland) Act 2003 establishes an inherent priority for its charging orders, meaning that model does not provide what has been called the 'iron-clad protection of its cousins'. ${ }^{65}$

\subsection{Statutory Charges over Land: Human Rights?}

Brief mention must be made of the human rights implications of a new statutory charge. Introducing such a charge would affect an owner's and indeed any secured creditor's peaceful enjoyment of property in a way that could engage Article 1 of the First Protocol ('A1P1') to the European Convention on Human Rights (the 'ECHR'). The manner of creation of a charge would also need to be compatible with Article 6 of the ECHR, which guarantees the right to a

\footnotetext{
${ }^{62}$ Birmingham Corporation v Baker (1881) 17 Ch D 782; Guardians of Tendring Union v Dowton [1891] 3 Ch 265; and Paddington Borough Council v Finucane [1928] Ch 567

${ }^{63}$ Haymarket (n 61) 680 (emphasis added).

64 ibid.

${ }^{65}$ Anderson (n 41) 35. The same is true of the Health and Social Services and Social Security Adjudications Act 1983, which provides (in section 23(6)) that a charging order under it has effect as if it were a standard security under the 1970 Act.
} 
fair hearing. ${ }^{66}$ These concerns are particularly pertinent to Scotland given the devolution settlement established by the Scotland Act 1998 does not allow the Scottish Parliament to legislate in a manner incompatible with the ECHR. ${ }^{67}$ That being the case, the simple fact that the Scottish Parliament has legislated to introduce such charges in certain circumstances (via the Housing (Scotland) Act 2006), which has not been challenged on ECHR grounds to date, offers a ready-made answer to any question of whether this issue can be navigated. To navigate this issue again, the Scottish Parliament would need to ensure future legislation was (in relation to property rights) proportionate and not arbitrary, ${ }^{68}$ and (in relation to fair hearing concerns) cognisant of giving anyone affected a meaningful role in the process of imposing ${ }^{69}$ and enforcing a first-ranking charge. States have a margin of appreciation within which to act in terms of $\mathrm{A} 1 \mathrm{P} 1 .^{70}$ This shifts the question to whether a charge can be justified on environmental protection grounds. That forms the next section of this article. The human rights of a landowner and secured creditors will be returned to thereafter.

\section{The Utility Question}

This section examines whether the environmental protection arguments justify introduction of the power and for the charge created under it to be first-ranking. This discussion, framed from the perspective of the policy rationales for the 'polluter-pays' principle of EU environmental

\footnotetext{
${ }^{66}$ Karl Construction Ltd v Palisade Properties plc 2002 SLT 312.

${ }^{67}$ Scotland Act 1998, s 29.

${ }^{68}$ Consider Salvesen v Riddell [2013] UKSC 22, where legislation passed by the Scottish Parliament was held to breach a landowner's ECHR rights, discussed in Malcolm Combe, 'Peaceful enjoyment of farmland at the Supreme Court' 2013 SLT (News) 201.

${ }^{69}$ Reference could be made here to the comparable English regime in the EPA 1990, where (in terms of section 78P) the enforcing authority must send a suitable notice detailing certain specific and generic information. The specific information would include the sum which the enforcing authority claims is recoverable, whilst generic information would explain the effect of the charge (as from 21 days of service, subject to appeal). On appeal, a court can confirm or strike out a charging notice, or it can substitute a different amount.

${ }^{70}$ AXA General Insurance Limited v The Lord Advocate [2011] UKSC 46.
} 
law, is applicable beyond Scotland to many jurisdictions considering implementing such a charge (or similar measure).

\subsection{Facing a Methodological Challenge}

It is important to highlight one methodological challenge to making a proper determination of the utility question. A clear distinction must be drawn between frameworks of environmental liability deriving solely from the domestic laws of Scotland (and England and Wales for comparative purposes) and those deriving from EU institutions; they cannot be conflated for analytical ease. In the latter, the 'polluter-pays' principle is firmly entrenched and, inter alia, guides policy development at the EU institution level. ${ }^{71}$ It is referred to expressly in various EU Directives, including the Landfill Directive ${ }^{72}$ and the ELD. ${ }^{73}$ The principle cannot be deemed to possess equivalent status in the domestic laws of Scotland, England or Wales. Their domestic rules do not refer to it expressly. For instance, the principle is not mentioned in the contaminated land regime in Part IIA of the Environmental Protection Act 1990, but there are references to it in the associated statutory guidance. ${ }^{74}$ Reference is made to it in the Explanatory Notes to certain Acts of Parliament applicable to both legal jurisdictions, notably the Energy Acts of 2008 and $2016 .{ }^{75}$ This indicates that the principle, considered as a 'principle' in its own right, has no formal status as a norm of domestic law. Even in the context of legislation which derives from EU law, only one piece of legislation in each jurisdiction which

\footnotetext{
${ }^{71}$ Consolidated versions of the Treaty on European Union and the Treaty on the Functioning of the European Union [2012] OJ C 326/01, art 191(2).

${ }^{72}$ Council Directive 1999/31/EC on the landfill of waste [1999] OJ L182/1 (the 'Landfill Directive'), recital five: 'Whereas under the polluter pays principle it is necessary, inter alia, to take into account any damage to the environment produced by a landfill.'

${ }^{73} \operatorname{ELD}(\mathrm{n} 22)$, art 1: the directive is 'based' on the 'polluter-pays' principle.

${ }^{74}$ DEFRA, Circular 01/2006, Environmental Protection Act: Part IIA - Contaminated Land (2006).

${ }^{75}$ See, eg Explanatory Notes to the Energy Act 2016 [2]; Explanatory Notes to the Antarctic Act 2013 [4]; Explanatory Notes to the Energy Act 2008 [30]; Explanatory Notes to the Water Act 2003 [495].
} 
enacts requirements of that law into the laws of Scotland ${ }^{76}$ and England and Wales ${ }^{77}$ explicitly refers to it in its text.

The methodological challenge that we face is that we must be sensitive to this legal culture in the UK when attempting to link the policy rationales underpinning that EU-specific principle to frameworks of purely domestic environmental liability in Scotland. The same is true in respect of legal jurisdictions outside the EU. As Scotford observes, whilst similarly named principles may 'trigger and reinforce' doctrinal developments within a jurisdiction, a name does not, 'indicate equivalent legal developments across jurisdictions. ${ }^{178}$ Nevertheless, she asserts that, 'any commonality' in name rests in its 'symbolism' and 'ability to stimulate legal change'. ${ }^{79}$ The latter is the hook to which this article hangs its analysis of the principle. Using the principle of EU law as a 'case study' of sorts, we tease out the diverse functions of, and justifications for, the imposition of corporate environmental liability in a society. This provides a lens through which to assess the case for legal change, ie whether introduction of the power in Scotland could facilitate those objectives and generate positive environmental outcomes.

\subsection{Analysing Utility through the Lens of the 'Polluter-Pays' Principle of EU Law}

We move now to elucidate the policy driving the emergence and subsequent development of the 'polluter-pays' principle of EU environmental law. Engagement with this literature enables us to explore a normative justification for the power, connecting the discussion to the larger, more complex question posed at the outset of this article regarding how law can drive more responsible and sustainable corporate conduct.

In EU environmental law, the principle may be seen to have three core policy rationales. Put another way, it has three first-order dimensions: equitable, economic and economic equity.

\footnotetext{
${ }^{76}$ The Water Environment (River Basin Management Planning: Further Provision) (Scotland) Regulations 2013/323, reg 15(2).

${ }^{77}$ Water Environment (Water Framework Directive) (England and Wales) Regulations 2017/407, reg 21(2).

${ }^{78}$ Scotford (n 18) 4.

79 ibid 5.
} 
It is prudent to note here that some commentators consider the principle to have only two firstorder dimensions: equity and economic. ${ }^{80}$ Others view these as 'alternative' justifications for liability, ${ }^{81}$ with one being 'incompatible' with the other. ${ }^{82}$ And the existence and relevance of the equitable dimension in the context of the ELD is disputed. ${ }^{83}$ With sensitivity to these observations, more on which will be said shortly, we contend that the principle possesses three distinct dimensions. The third builds upon the logic of the other two but is separate to them: an 'economic equity' dimension. ${ }^{84}$ Whilst some commentators consider it to be 'political' in nature, ${ }^{85}$ we consider the 'economic equity' label to encapsulate more fully the economic role which the principle plays in intra-EU trade. And this can, with adjustment, help us analyse the wider effects of the current inapplicability of the power in Scotland. Recognition of these three distinct policy considerations prevents discussion of that question being distilled down to a single narrative, that of cost internalisation and notions of economic efficiency. Whilst relevant, it need not be the dominant narrative for the principle's basis in environmental policy. These dimensions will now be considered.

\subsubsection{Equitable dimension}

\footnotetext{
${ }^{80}$ MN Boeve and GM van den Broek, 'The Programmatic Approach: a Flexible and Complex Tool to Achieve Environmental Quality Standards' (2012) 8 Utrecht L Rev 74, 80-81; John Alder and David Wilkinson, Environmental Law \& Ethics (Macmillan 1999) 171.

${ }^{81}$ Arne Bleeker, 'Does the Polluter Pay? The Polluter-Pays Principle in the Case Law of the European Court of Justice' (2009) 18 EELR 6 289, 290; Lees, 'The Polluter Pays Principle' (n 17) 6.

${ }^{82}$ Lees, 'The Polluter Pays Principle' (n 17) 6.

${ }^{83}$ Valerie Fogleman, 'Polluter pays principle for accidental environmental damage; implementation in the Environmental Liability Directive' in Allessandro D'Adda, Ida Angela Nicotra and Ugo Salanitro (eds), Principi Europei e Illecito Ambientale (Giappichelli Editore 2013) 126 and 142.

${ }^{84}$ Sanford Gaines, 'The Polluter-Pays Principle: From Economic Equity to Environmental Ethos' (1991) 26 Tex Int'l LJ 463, 470.

${ }^{85}$ Hans Christian Bugge, 'The Polluter Pays Principle: Dilemmas of Justice in National and International Contexts' in Jonas Ebbesson and Phoebe Okowa (eds), Environmental Law and Justice in Context (CUP 2008) 414.
} 
This dimension represents the value judgement of a legislator, and so a society, that there is something intuitively fair and appropriate in imposing the costs of remedying pollution upon the person(s) responsible for the pollution. The manner in which that judgement is embedded within a framework of environmental liability will be a matter of policy and, perhaps, politics but it requires a nexus to be drawn between a person and the harm; the notion of 'responsibility' must be grounded in concrete terms. For instance, under the ELD, the responsible person (ie the 'operator') is the person who 'operates' or 'controls' the activity which caused the environmental damage or the imminent threat of it. ${ }^{86}$ The value judgement, operationalised within that (or, indeed, any) framework by the chosen nexus, sets the target against which the cost-internalising function of the principle (ie the economic dimension) operates. Thus, the principle's equitable and economic dimensions are not mutually exclusive as some commentators suggest but, in fact, work together.

Overt references to this dimension appear in both the jurisprudence of Advocate General Kokott and the academic commentary. For AG Kokott, in addition to its efficiencyfocused economic dimension, "[t]he "polluter pays" principle also has the aim of fair allocation of the costs of environmental pollution. The costs are not imposed on others, in particular the public, or simply ignored, but assigned to the person who is responsible for the pollution. ${ }^{187}$ The Court of Justice of the European Union (CJEU) does not refer explicitly to the idea that the principle possesses an equitable dimension. Instead, it emphasises that the obligation to remedy pollution must lie with those who contribute to its creation. ${ }^{88}$ Some see the imposition of costs upon those responsible for, or through analogy those who have contributed to the creation of, pollution to be fundamental, logical, and fair. ${ }^{89}$ For others it is intuitively normal or

\footnotetext{
${ }^{86} \operatorname{ELD}(\mathrm{n} 22)$, arts 2(6)-(7) and 3.

${ }^{87}$ Case C-254/08 Futura Immobiliare Srl Hotel Futura v Comune di Casoria [2009] ECR I-6995, Opinion of AG Kokott, [32] (emphasis added).

${ }^{88}$ See, eg C-379/08 Raffinerie Mediterranee (ERG) SpA v Ministero dello Sviluppo Economico [2010] ECR I-2007 [67].

89 Jonathan Nash, 'Too Much Market? Conflict between tradable pollution allowances and the "polluter pays" principle' (2000) 24 Harv Envtl L Rev 465, 466; Boeve and van den Broek (n 80) 80-81; Bleeker (n 81) 290.
} 
just. ${ }^{90}$ Upon these perspectives, the principle expresses a moral judgement about the allocation of responsibility for environmental protection in society, ${ }^{91}$ providing an 'attractive alternative' to understandings of environmental liability based purely on the ideal of efficiency. ${ }^{92}$ Indeed, for Scotford, the very idea of an environmental 'principle' reflects 'forceful ethical considerations' and carries 'moral weight' in itself. ${ }^{93}$ The (successful) imposition of environmental costs upon the responsible person may be seen to respect and further the preconfigured conception of fairness embedded within the principle, with the power being one way of achieving this.

There is, however, the argument that the principle does not possess an equitable dimension. ${ }^{94}$ For Fogleman, the principle, as enunciated in EU environmental law, is and always has been a cost allocation principle, not a liability principle. ${ }^{95}$ Thus, fairness has little to do with how costs are allocated after they arise. Fogleman draws upon the example of the ELD which allocates costs 'without regards to the ultimate liability'. ${ }^{96}$ Under the principle as articulated in the ELD, costs may be allocated to an 'operator' in circumstances where it neither caused the environmental damage nor created the imminent threat of it. For instance, under Article 8(3)(a) of the ELD, an operator is not required to bear the cost of preventive or remedial actions undertaken when it can prove that the damage or its imminent threat, 'was caused by a third party and occurred despite the fact that appropriate safety measures were in place.'

\footnotetext{
${ }^{90}$ Bugge (n 85) 420; Sally-Ann Joseph, 'The Polluter Pays Principle and Land Remediation: A Comparison of the United Kingdom and Australian Approaches' (2014) 1 AJEL 24, 26; Maria Lee, "New' Environmental Liabilities: The Purpose and Scope of the Contaminated Land Regime and the Environmental Liability Directive' (2009) 11 ELR 264, 267.

${ }^{91}$ Gaines (n 84) 496; Nicholas Ashford and Charles Caldart, Environmental Law, Policy, and Economics: Reclaiming the Environmental Agenda (MIT Press 2008) 175.

${ }^{92}$ Lee (n 90) 267.

${ }^{93}$ Scotford (n 18) 35 and 36.

${ }^{94}$ Charles Pearson, 'Testing the System: GATT + PPP = ?' (1994) 27 Cornell Int'I LJ 553, 556; Fogleman (n 83 ) 134

${ }^{95}$ Fogleman (n 83) 126 and 142.

${ }^{96}$ ibid 126 and 130
} 
This exemption will apply to situations like sabotage.${ }^{97}$ However, Article 8(3) then asserts that 'Member States shall take the appropriate measures to enable the operator to recover the costs incurred.' The operator bears first responsibility for the costs but they can seek to recover them from the party which caused them. There is, however, no guarantee that the third party (eg a contractor) will be in the financial position to bear the costs, or even that they can be located, as may be the case with a vandal. If not, the operator must bear them.

The channelling of costs to the operator where it neither caused the damage nor created the imminent threat of it may be seen to contradict the assertion that the principle possesses an equitable dimension. However, for AG Kokott, the EU legislature has, through its inclusion of exemptions in article 8, created a regime of cost apportionment which it regards to be 'equitable'. ${ }^{98}$ This acknowledges that whilst it may not be equitable from the operator's perspective (as de jure polluter) that it must bear the costs associated with damage caused by a third party (the de facto polluter), this allocation is equitable from the perspective of the framework as a whole and what that framework seeks to achieve: the prevention and remedying of environmental damage. ${ }^{99}$ This position prioritises protection of public funds and the environment over the capital of the de jure polluter.

Thus, we contend that the equitable dimension of the principle is furthered when environmental costs are allocated to the person defined under statute as the party responsible for them. This may or may not be the actual (ie de facto) polluter. Adherence to the statutory definition of the responsible person will regulate the boundaries within which a company can reasonably be deemed to be 'responsible' for pollution and so upon whom it is proper to take a charge on their land; that definition sets the parameters of 'fairness'. It may expand the causal link well beyond causality in the tortious (or delictual, for Scots readers) sense but this is entirely compatible with the principle and its equitable dimension. As Lees observes, the

\footnotetext{
${ }^{97}$ Case C-534/13 Ministero dell'Ambiente e della Tutela del Territorio e del Mare v Fipa Group Srl ECLI:EU:C:2014:2393, Opinion of AG Kokott, [33].

${ }^{98}$ Raffinerie Mediterranee (n 88), Opinion of AG Kokott, [99].

${ }^{99} \operatorname{ELD}(\mathrm{n} 22)$, art 1.
} 
principle does not demand that causation is the only justification for requiring a person to remediate pollution. ${ }^{100}$ This conception of fairness aligns with the logic that, as a general rule, 'polluters are the parties who are able to take the most effective [preventive] measures.'101 Thus, attributing responsibility for pollution, including via the power, to the de jure polluter is justifiable where there has been a failure to prevent it from occurring. With the knowledge that they must bear the costs associated with environmental obligations for which they are deemed responsible, the responsible person will take the measures necessary to prevent the damage occurring in the first place. ${ }^{102}$ For instance, security at the site could be bolstered and they could undertake risk assessments where contractors required access to the site, implementing appropriate safeguards where necessary. They could also utilise contractual means of mitigating the risk to which they would be exposed should damage occur. This may be through environmental impairment liability (EIL) insurance to cover the costs of environmental damage ${ }^{103}$ including that caused by third parties coming on to the site. Contractors granted access to the site could also be required to hold it or evidence other appropriate financial provision for environmental liabilities to which they may become subject.

The measures available to regulators in Scotland do express a moral judgement (and so do further this dimension) in the sense that they allocate environmental costs to an operator and enable court action for a judicial charge to be taken in that operator's land for those costs. But, that moral judgement cannot be operationalised in a manner which impresses appropriate weight upon an operator. Without executing diligence (ie debt enforcement via court action), the regulator would be vulnerable to the operator's insolvency prior to collection of the debt. And even with a judicial charge the regulator's charge would rank behind any charges created at an earlier date. The lack of priority accorded to judicial charges raises two issues as regards their capacity to impress moral judgement. First, where there is an existing charge (or charges)

\footnotetext{
${ }^{100}$ Lees, 'Should the "Polluter" Pay?' (n 17) 107.

${ }^{101}$ Fipa Group (n 97), Opinion of AG Kokott, [55].

102 ibid.

${ }^{103}$ EIL policies are tailored to provide protection to policyholders in respect of unforeseen environmental liabilities.
} 
registered against a heritable property there may be insufficient value remaining in it upon which the judicial charge can attach. Second, incentives for companies and their shareholders to take action to avoid the reach of judicial charges are generated. Within the context of the implications of not according priority status to a statutory charge, this was acknowledged by Lord Denning in Haymarket. ${ }^{104}$ He used the (quite lawful) example of a holding company providing a loan to its subsidiary to purchase land, with a charge being granted in its favour over the full estimated value of the land. Unless this value increased over time, there would be nothing to secure a judicial charge against should an environmental regulator need to recover its costs in the future. In both cases, as the value upon which the judicial charge can attach lessens (or disappears), so too does its capacity to impress moral judgement upon the operator. A first-ranking charge offers a solution to both issues.

\subsubsection{Economic dimension}

This dimension underpins the principle's theoretical basis. It has its foundations in economic theory and seeks to correct market failure. ${ }^{105}$ When an operator does not pay for the damage which its activities cause to the environment it need not reflect these costs in the price charged for its goods or services. ${ }^{106}$ These unpriced costs, referred to by economists as negative externalities, are transferred to society and are considered a form of market failure. ${ }^{107}$ As consumers (as opposed to wider society) benefit from market prices that do not reflect the true social cost of the relevant activity then there is greater demand for those goods or services. ${ }^{108}$

\footnotetext{
${ }^{104}$ Haymarket (n 61) 681.

${ }^{105}$ Case C-126/01 Ministre de L'économie, Des Finances et de L'industrie v GEMO SA [2003] ECR I-13769, Opinion of AG Jacobs, [66].

${ }^{106}$ Anthony Ogus, Regulation: Legal Form and Economic Theory (first published 1994, Hart Publishing 2004) 35.

107 ibid 21 and 35.

${ }^{108}$ Nicholas de Sadeleer, Environmental Principles: From Political Slogans to Legal Rules (OUP 2002) 21.
} 
More is produced than is socially efficient. ${ }^{109}$ And competitors who do bear their environmental costs are at a competitive disadvantage in the market to those that do not. The principle's economic dimension responds to this by seeking to make the polluter (ie the responsible person under the statute) 'internalise' its environmental costs.

The first-ranking charge in favour of the regulator is one enforcement tool through which an operator's environmental costs may ultimately be internalised. It has the capacity to encourage reluctant operators to fulfil their obligations in order to avoid a charge being placed on their land or where their financial position does not permit payment by lump sum, to agree a suitable payment schedule. Failing that, exercising their power of sale under the charge would enable the regulator to sell the land with a view to recovering the debt secured by it. Costs may not be recovered fully under prevailing mechanisms in Scotland owing to the rarity of their usage, the prospect of their being placed behind prior-ranking creditors, and the simple techniques described in the previous section which may thwart their utility.

Deployment of a first-ranking charge upon land (or the threatened invocation of it) would confer various benefits upon society, each of which flows from furtherance of this dimension. First, market-orientated incentives are created for those who may cause environmental damage to avoid doing so. ${ }^{110}$ This 'upstream' benefit of cost internalisation gives the principle an important environmental protection perspective. ${ }^{111}$ The incentivising potential of successful utilisation of the charge, or phrased negatively, its deterrent effect, ${ }^{112}$ derives from the fact that 'potential polluters who know they will be liable for the costs of remedying the damage they cause have a strong incentive to avoid causing such damage. ${ }^{113}$ It is

\footnotetext{
109 Ogus (n 106) 19 and 35; Genevra Richardson, Anthony Ogus and Paul Burrows, Policing Pollution: A Study of Regulation and Enforcement (Clarendon Press 1982) 4.

${ }^{110}$ Raffinerie Mediterranee (n 88), Opinion of AG Kokott, [85-86]; Fipa Group (n 97), Opinion of AG Kokott, [55]; Michael Faure, 'Regulatory Strategies in Environmental Liability' in Fabrizio Cafaggi and Muir Watt (eds), The Regulatory Function of European Private Law (Edward Elgar 2009) 132.

${ }^{111}$ Futura Immobiliare (n 87), Opinion of AG Kokott, [31].

112 Faure (n 110) 132

${ }^{113}$ Commission, 'Green Paper on Remedying Environmental Damage' COM(93) 47 final, 5.
} 
economically rational for them to increase their level of care when undertaking the activity and/or decrease the actual level of the activity. ${ }^{114}$ The decision will, generally, be left up to the operator as to the optimal mode of preventing environmental damage. ${ }^{115}$ Corporate decisionmakers will decide whether to cease or reduce activity, lower the level of pollution which the company's activities cause or, alternatively, continue as normal and meet the remediation costs if and when required. ${ }^{116}$ The latter behaviour would be exhibited by the 'rational polluter' for whom the marginal benefit of undertaking the infringing action was greater than the marginal cost of doing so; there may be net benefit to their infringement of environmental law. As Hofstetter contends, 'corporate culture, by its nature, cannot be fine-tuned by law, though it can be influenced by legal signals'. ${ }^{117}$ For frameworks of environmental liability in any jurisdiction to be effective, they must be capable of affecting the decisions made in boardrooms; they must send the appropriate 'legal signal'. Thus, whilst introduction of the power cannot, in itself, force behavioural change, it offers one legal signal through which culture may be recalibrated and change encouraged.

Second, the cost of producing the goods or providing the services would more accurately reflect the environmental costs attributable to them. Their price may increase because of the newly internalised environmental costs or the increased costs associated with the operator's attempt to prevent the environmental costs from arising in the first place (eg through investment in safety measures). ${ }^{118}$ Important indirect or 'downstream' benefits flow from this which link consumer preferences with more sustainable corporate behaviour. Consumer preferences for lower priced goods and services may decrease demand for goods

\footnotetext{
${ }^{114}$ Lucas Bergkamp, Liability and Environment: Private and Public Law Aspects of Civil Liability for Environmental Harm in an International Context (Kluwer Law International 2001) 87.

${ }^{115}$ Faure (n 110) 132.

${ }^{116}$ Futura Immobiliare (n 87), Opinion of AG Kokott, [31].

${ }^{117}$ Karl Hofstetter, 'The Ecological Liability of Corporate Groups: Comparing US and European Trends' in Gunther Teubner, Lindsay Farmer, and Declan Murphy (eds), Environmental Law and Ecological Responsibility: the Concept and Practice of Ecological Self-organization (John Wiley \& Sons 1994) 110.
}

${ }^{118}$ Bugge (n 85) 413. Whether the price does, in fact, increase will depend on price elasticity and other market conditions: ibid. 
or services whose price is high due to internalised environmental costs. ${ }^{119}$ Thus, operators have an economic incentive to minimise their potential environmental costs, ${ }^{120}$ an option being to reduce the risk of a pollution incident arising or limiting the scale and the impact of one should it occur. Those operators no longer able compete in the market due to a resulting escalation in the price of their good or service may be forced to leave it.

The enforcement tools currently available to SEPA are wide and varied, including a capacity to impose fixed and variable monetary penalties and accept offers proposed by operators to provide a solution to their non-compliance (ie enforcement undertakings). ${ }^{121}$ These remedies may be useful in certain situations, such as where the operator possesses the funds and inclination to both fall back into compliance and restore and remediate environmental harm. However, they offer no protection should SEPA need to undertake an operator's unfulfilled environmental obligations. Nor do the usual remedies for debt recovery in Scotland. Through affording an opportunity to internalise the operator's environmental costs, the proposed power provides a powerful means of facilitating the intent underpinning SEPAs enforcement policy and helping it fulfil its statutory purpose of 'protecting and improving the environment'. ${ }^{122}$ As we have seen, the power has the capacity to protect the environment through changing the behaviour of operators via the economic incentives which it generates, a key focus of SEPA's enforcement policy. ${ }^{123}$ And through giving comfort to SEPA that if it carries out works on the operator's behalf then the associated costs will be recoverable, not only could the power stop or, at the very least, reduce the risk of (further) harm arising from

\footnotetext{
${ }^{119}$ Bergkamp (n 114) 69.

${ }^{120}$ Bleeker (n 81) 291.

${ }^{121}$ Regulatory Reform (Scotland) Act 2014 (asp 3) pt 3 c 2.

${ }^{122}$ Environment Act 1995, s 20A(1); SEPA, The Scottish Environment Protection Agency's Enforcement Policy: Introduction to Enforcement Policy, 1 <https://www.sepa.org.uk/media/219244/enforcement-policy.pdf> accessed 24 June 2018. 123 ibid.
} 
the non-compliance, ${ }^{124}$ it also improves the possibility of the environment being restored and remediated. ${ }^{125}$ The latter is something that SEPA states should occur 'wherever possible'. ${ }^{126}$

\subsection{3. 'Economic equity' dimension}

This dimension reflects the original policy rationale for the principle and seeks to establish a common standard to prevent states from giving domestic businesses a competitive edge in world markets through subsidies. ${ }^{127}$ The principle was developed by the Organisation for Economic Co-operation and Development (OECD) in the early 1970 s as an economic rule to avoid distortion of international trade. ${ }^{128}$ When industrialised nations sought to remedy their environmental problems in the late 1960s, there was a concern that some states would use public funds to subsidise private pollution control. ${ }^{129}$ For states adopting strong environmental protection positions, new costs would be imposed upon their manufacturers. ${ }^{130}$ Thus, state subsidisation of those costs would give those companies a significant price advantage in the global market. The (non-binding) OECD Council Recommendation on Guiding Principles Concerning the International Economic Aspects of Environmental Policies sought to address this. ${ }^{131}$ Founded upon the tenet that the polluter, not domestic governments, should bear the expense of pollution prevention and control measures, these costs were to be reflected in the

\footnotetext{
124 ibid.

125 ibid.

${ }^{126}$ SEPA, Guidance on the Use of Enforcement Action (June 2016) $22<$ https://www.sepa.org.uk/media/219242/enforcementguidance.pdf> accessed 24 June 2018.

${ }^{127}$ Gaines (n 84) 471.

${ }^{128}$ OECD, 'Recommendation of the Council on the Implementation of the Polluter-Pays Principle' (1974) C(74)223; OECD, 'Recommendation of the Council on Guiding Principles concerning International Economic Aspects of Environmental Policies' (1972) C(72)128.

${ }^{129}$ Gaines (n 84) 465-466.

130 ibid 466

${ }^{131}$ OECD (n 128).
} 
price of goods and services. ${ }^{132}$ This 'economic equity' dimension met the immediate tradeharmonisation needs of the then EC which soon incorporated the principle into its emerging environmental policies. ${ }^{133}$

Whilst this dimension is framed within the context of international and intra-EU trade, analogies can be drawn with intra-UK trade. Failure by a legislature to empower regulators within that jurisdiction to take a first-ranking charge upon the heritable property of a polluter could be conceptualised as facilitating a voluntary advancement of 'credit' to that operator. The 'credit' advanced comes from state resources and may be considered to comprise two types of capital. First, there is 'financial capital' where taxpayer funds were utilised by the regulator to undertake the operator's environmental obligations. Second, there is 'ecological capital' where the environment remained in an unrestored or unremediated state following a decision by the regulator that it would not undertake the works. The advancement of credit may have an effect similar in nature to positive economic assistance - such as a subsidy or unsecured loan - by that state. There is thus potential for distortions of trade and competition between operators in jurisdictions whose legislative framework enables the charge to be taken and those that do not. In the case of the latter, operators may externalise their costs (strategically or otherwise). In the former, they cannot, or at least cannot do so as easily. As we have seen, operators who can externalise their costs can offer lower priced goods or services than those that cannot, creating false price signals to the market and sending inappropriate messages to industry.

There is an alternative angle on this point, one emphasised in the debates in the UK Parliament regarding the charge (or lack thereof) in Scotland. That was the impact on taxpayers and the use to which council tax - a local tax which helps fund municipal services was applied. In the context of a proposal for Scottish local authorities to have the power to

\footnotetext{
132 ibid Annex para A.4.

${ }^{133}$ Gaines (n 84) 470; See, eg Council Recommendation 75/436/Euratom, ECSC, EEC of 3 March 1975 regarding cost allocation and action by public authorities on environmental matters [1975] OJ L194/1 [1].
} 
make a charging order in the same manner as their English counterparts, in the Commons a Scottish MP asserted that: 'As the Bill stands, council tax payers in Scotland would be disadvantaged because of that dissimilarity in the legal provisions [with those in England]. ${ }^{134}$ They would be disadvantaged as taxpayers' funds would, in the absence of a first-ranking charge, be more difficult to recover in Scotland whereas they would, in similar factual circumstances, be recoverable in England. In consequence, lost 'financial capital' could not be used to fund necessary public services.

Introduction of the power in Scotland is one means through which these distortions in trade, competition and parity in the utilisation of tax could be redressed. The jurisdiction from which an operator traded would offer no competitive advantage in this regard. The charge would also reduce the prospect of financial and ecological capital being expended to fulfil an operator's environmental obligations.

\subsection{Generating Utility through the Private Ordering of Relationships}

A power facilitative of the above policy rationales may also generate more responsible and sustainable corporate conduct through the private ordering of relationships between operators and creditors (secured and unsecured) that would be expected to flow from its introduction. It could induce operators and creditors to be more aware and careful of the consequences of their actions and decisions. The incentive derives from the fact that a potential secured creditor would know, prior to lending, that any charge it might take was susceptible to a regulator's charge and (unsecured) trade creditors would know that the charge could deplete the pool of assets available to the general body of unsecured creditors should the operator enter into insolvent liquidation.

First, this recognition could encourage secured creditors and trade creditors to be (more) rigorous in their due diligence, perhaps undertaking a risk assessment of the operator's

\footnotetext{
${ }^{134}$ HC Deb 28 June 1995, vol 262, col 957 (Mr Sam Galbraith MP).
} 
environment impacting activities prior to dealing with the operator. ${ }^{135}$ This would 'flag' operators with particularly high-risk activities or poor safety records as higher risk debtors, meaning that the creditor could walk away, impose more restrictive trading requirements or lend under terms and at a rate reflective of that risk. ${ }^{136}$ Under such market conditions, operators would be encouraged to decrease their environmental risk profile to become a more attractive debtor. If they did not, market dissatisfaction with their environmental practices could render them unable to obtain satisfactory credit rates and terms. But, where secured and trade creditors enter relationships with an operator engaged in activities which could harm the environment in circumstances where they knew that the statutory charge would be first-ranking then they should be deemed to have accepted the associated commercial risks of doing so. After all, the ultimate decision whether, and upon what terms, to trade with any operator lies with them.

Second, and relatedly, a secured creditor could mandate that the operator hold appropriate financial provision (eg EIL insurance) throughout the period of the loan. ${ }^{137}$ For instance, in the case of EIL insurance, where an insured event occurred then the policy would provide a source of private funds to remediate the damage caused, furthering the powerful policy rationales for the 'polluter-pays' principle discussed above. Where the payment was sufficient to meet the operator's liabilities, the lender's investment would be protected; there would be no need for the regulator to take a first-ranking charge over the operator's heritable property. Not only could EIL insurance counteract some of the commercial consequences for the lender attributable to 'slide' in the priority of its charge and any unfairness perceived to flow from this, it could prevent the liability tipping the operator into insolvency, benefiting the general body of unsecured creditors indirectly. Where payment under the policy was insufficient to meet the liability and the operator was not in a financial position to 'plug' the gap with its own

\footnotetext{
${ }^{135}$ David Leebron, 'Limited Liability, Tort Victims, and Creditors' (1991) 91 Colum L Rev 7 1565, 1643; John Armour, 'Who Pays When Polluters Go Bust?' (2000) 116 LQR 200, 203.

136 Leebron (n 135) 1584; Armour (n 135) 203.

${ }^{137}$ Leebron (n 135) 1644.
} 
funds, then the lender's investment would be at risk (although, this risk would be lower than where the policy did not exist). Nevertheless, a secured creditor's commercial imperative to reduce the risk of its charge being overridden generates the prospect for a lack of public ordering (ie under statute) of the requirement for adequate financial provision to be compensated for by a private ordering (ie contractually) of it under the loan agreement. Operators and lenders can, therefore, redress through private bargain the downsides associated with trends in financial provision (or lack thereof) to which Scotland and other jurisdictions are exposed. A first-ranking charge would energise this regulatory innovation.

\section{The Implementation Question}

This section sets out our recommendations as to how the regulatory potential of the power could be harnessed by a legislator. Whilst we will not propose exact drafting, we will highlight two areas of particular importance: the priority and the scope of the charge.

As we have seen, the issue of priority plagues the utility of the mechanisms available to environmental regulators in Scotland, notably the judicial security. ${ }^{138}$ It is, however, crucial to maximising the utility of any power conferred upon its regulators to take a charge. The issue can be redressed with relative ease by both legislator and draftsperson. Within Scotland, drafting models for priority exist for comparator Scottish securities in terms of paragraph 4 of Schedule 9 of the Housing (Scotland) Act 1987 and s 173(2)(b) of the Housing (Scotland) Act 2006. The latter deals neatly with the issue. It provides that the charge ranks above 'all' future and existing 'burdens and incumbrances on the same property' albeit with certain narrow exceptions. Environmental laws of Singapore ${ }^{139}$ and the Australian states of New South Wales $^{140}$ and Victoria ${ }^{141}$ provide further models. They are also explicit in conferring absolute

\footnotetext{
${ }^{138}$ See the text accompany nn 29-32.

${ }^{139}$ EPMA 2002 (n 5) s 53(1).

${ }^{140}$ CLMA 1997 (n 6) s 40(3).

${ }^{141}$ EPA 1970 (n 6) s 62(12).
} 
priority to the regulator's charge. And whilst Tasmania ${ }^{142}$ and Western Australia ${ }^{143}$ rank the regulator's charge equally with other statutory charges, they confer priority over those created in favour of third parties.

If the proposed power was implemented by the Scottish Parliament (or, indeed, any legislature) and imposed where there was an existing charge over the same land this could be perceived as unjust and inequitable as to the legitimate rights of the chargeholder. This could be redressed through an appropriate period of transition where the statutory charge was widely trailed as gaining prior-ranking status in respect of competing charges taken after a specified date. Prior charges would not be impacted, ensuring the integrity of the proposed power. All interested participants would have time to adjust and the opportunity to protect themselves contractually from perceived areas of commercial risk, with insurance being one particularly useful medium. Another solution would be for loan agreements entered after the specified date to mandate that the borrower seek prior approval from the secured creditor if they are to enter new lines of business from which environmental obligations may be incurred.

Prioritising the charge over third party charges created at an earlier date could impact on the availability and cost of credit. ${ }^{144}$ Creditors may be less inclined to advance funds to, or enter into trade with, operators engaged in certain industrial sectors. Or, they may be willing to do so only at a high interest rate, under stricter trading terms or in tandem with the provision of appropriate insurance. But, to restate our position: failing to accord priority to the regulator's charge could render fulfilment of the important policy rationales underpinning the 'polluterpays' principle unattainable. The potential impact on the availability and cost of credit could be counteracted by appropriate financial provision being made by the operator. This would, presumably, influence the assessment of the operator's environmental risk by secured and trade creditors and so of the risk to which their credit was exposed. Secure and sufficient

\footnotetext{
142 EMPCA 1994 (n 6) s 74V(6).

${ }^{143}$ CSA 2003 (n 6) s 32(3)(a).

${ }^{144}$ Leebron (n 135) 1584.
} 
financial provision would reduce, albeit not eliminate, the need for the power to be utilised in the first place. As such, the statutory charge and any discussion as to its priority as compared with other earlier charges would be rendered less significant where appropriate and adequate financial provision was present prior to activity being commenced. But, in the absence of these conditions - and these are absent in many sectors - its significance comes to the fore.

Another important consideration is the scope of a charge. What heritable property should be secured under the power? An initial point is that there is no reason for Scotland (or any other jurisdiction) to restrict the scope of the charge to property that is owned outright by an operator: a charge could also be effective in relation to a lease. ${ }^{145}$ As for the area of land encumbered, the charging model for demolition of a building under section 131(3) of the Housing (Scotland) Act 1987 allows for slightly more than the footprint of that building itself to be caught, so there is a tentative precedent for extending the scope of the charge beyond the footprint of a building affected by any remedial action. ${ }^{146}$

Consideration should also be made of the 'any premises' wording of the Environmental Damage (Prevention and Remediation) (England) Regulations 2015. ${ }^{147}$ This affords a drafting technique that would maximise the utility of the power. There, funds are recoverable by the relevant regulator from an operator who is the 'owner of any premises', with the costs incurred by the regulator and accrued interest being recoverable via a charge on 'the premises'. ${ }^{148}$ The current English Regulations, implemented on 19 July 2015, delivered a subtle drafting change. They introduced the word 'any' when the old drafting merely referred to recoverability from 'a person who is the owner of premises'. ${ }^{149}$ The intended effect of the revised drafting of the English Regulations (ie the inclusion of 'any') is not clear but what is clear is that Parliament

\footnotetext{
${ }^{145}$ In Scotland, this would be possible with a 'long lease' (a lease exceeding twenty years in duration).

${ }^{146}$ Consider also s 78P EPA 1990 which allows for security over more than a contaminated area where it is part of larger premises.

${ }^{147}$ English Regulations (n 4).

148 ibid reg 27(1) (emphasis added).

${ }^{149}$ Environmental Damage (Prevention and Remediation) Regulations 2009, SI 2009/153, reg 27(1).
} 
intended to break from prior drafting and, presumably, its effect. ${ }^{150}$ One interpretation is that the revised drafting enables regulators to be selective about the particular premises to which the charge would attach. Thus, where the operator held a portfolio of heritable property then the regulator could 'cherry pick' the property with the greatest prospect of generating a successful sale. For instance, city centre office premises could be considered more marketable than industrial premises subject to environmental damage. The size and buoyancy of the target market may also be an important consideration. Selectivity also increases the regulator's negotiating power. For instance, a charge over valuable city centre premises would hinder, and even perhaps prohibit, that piece of land from being used to secure future debt finance; lenders may be less willing to lend without priority for their security. The threat to an operator's future borrowing capacity may encourage payment or more sincere discussions as to an appropriate payment plan. Other jurisdictions confer this right of selectivity explicitly under statute. For example, under s $74 \mathrm{~V}(1)$ of the Environmental Management and Pollution Control Act 1994 of Tasmania, a charge may be taken 'on any land owned by the owner of [the] area of land' on which works were carried out.

Alternatively (or, indeed, additionally) the phrase 'the premises' could be interpreted in the plural. To utilise an example, consider a scenario in which an operator owned two heritable properties: a city centre office and industrial premises. Where the regulator incurred $£ 100,000$ fulfilling the operator's environmental obligations flowing from activities conducted at its industrial premises, then individual sums of $£ 50,000$ could be secured against each of the premises. This could be beneficial from the perspective of the operator, as a smaller secured amount would leave some 'headroom' should they wish to use an asset to raise debt finance in the future. It could be marginally less beneficial from the perspective of the regulator, owing to the need for enforcement against two properties. However, this option may be useful where

\footnotetext{
${ }^{150}$ See Oliver Jones, Bennion on Statutory Interpretation (6th edn, LexisNexis 2013). Whilst legislation is to be read as a whole, every word is to be given meaning and (regarding that latter point) section 355 explains: 'On the presumption that Parliament does nothing in vain, the court must endeavour to give significance to every word of an enactment. It is presumed that if a word or phrase appears, it was put there for a purpose and must not be disregarded.'
} 
the costs associated with unmet environmental obligations are large and the operator has a portfolio of heritable property.

All this said, the interests (and human rights) of a creditor holding a fixed security over an environmentally 'clean' site that could find its security subordinated to a statutory charge because of environmental liabilities incurred elsewhere would need to be considered carefully. This would especially be the case where those activities commenced after the constitution of that security or in a way that the secured creditor had no way of knowing about. For the Scottish Parliament to introduce a statutory charge with the potential to affect land beyond where industrial operations have taken place, it would need to legislate sympathetically and within the margin of appreciation afforded by A1P1 to the ECHR in a way that was not manifestly unreasonable. ${ }^{151}$

With appropriate and express provision on matters of priority and scope in statute, Scots law would be able to develop a useful and suitable regime which would consider the interests of operators, their secured and unsecured creditors, and wider society. Provided there is publicity in relation to those heritable properties affected by the charge (through registration in the Land Register), that would not jar with the principles underlying Scots land law. And provided any charge introduced only affected relevant land in a non-arbitrary manner and with due process, legislation could be produced that would cater for human rights considerations.

\section{Conclusion}

\footnotetext{
${ }^{151}$ AXA General Insurance Limited v The Lord Advocate [2011] UKSC 46. That case related to the Damages (Asbestos-related Conditions) (Scotland) Act 2009 (asp 4) and the imposition of financial liability by legislation where previously there was none. Even though that legislation survived a human rights-based challenge, the experience drawn from that case and the later case of Salvesen v Riddell [2013] UKSC 22 might lead the Scottish legislator to adopt a conservative approach to legislation to minimise litigation potential.
} 
This article has examined the viability and utility of introducing a statutory power in Scotland enabling its environmental regulators to take a first-ranking charge over land in respect of costs incurred by them in undertaking the unfulfilled environmental obligations of a recalcitrant or financially distressed operator. It made two original contributions to the literature, the latter of which is pertinent to other jurisdictions considering implementing such a power. First, contrary to established thought, Scots land law can be receptive to statutory charges for environmental liabilities provided there is appropriate publicity, but for charges created under statutory power to outrank prior charges this would need to be specified explicitly in statute. Second, the charge was demonstrated to have an important role to play in fulfilment of the 'first order' policy rationales for the 'polluter-pays' principle of EU environmental law, specifically ensuring a fair allocation of environmental costs in society, internalisation of an operator's environmental costs and avoiding distortions in trade created through state subsidisation of those costs. Certain 'second order' policy rationales were also identified which centred on generating more responsible and sustainable corporate conduct through cost internalisation, each of which may be facilitated by a first-ranking charge. The cost recovery mechanisms currently available to environmental regulators in Scotland were shown to offer inferior ability to fulfil these owing to their failure to accord prior-ranking status to the regulator's charge. Thus, the environmental protection arguments were believed to provide a strong normative justification for the introduction of the power and for the charge created under it to be first-ranking.

However, on its own, the power may not guarantee the full recovery of costs by regulators. First, the land subject to the charge needs to be sold to recover the funds and prevailing market conditions and demand for that particular piece of heritable property may impact upon the timeliness of a sale and the price achieved. Second, there may be evasive behaviour by operators. Introduction of the power could stimulate transfers of land to other group companies, with leases being granted to the operator in terms sufficiently short to ensure they too would not be subject to a statutory charge (to the extent such steps would not impact the capacity of companies to generate debt finance against the value of the land). There is, however, no evidence that this type of behaviour occurred when the power was legislated for 
in England and Wales. Nevertheless, secure and sufficient financial provision evidenced prior to commencement of operations, such as by way of insurance, bonds and cash deposits, offers a greater prospect of ensuring that funds are available to undertake environmental obligations as and when required. In its absence, and it is absent in some important frameworks applicable in Scotland (as it is elsewhere), the charge offers a valuable enforcement tool for regulators to protect both taxpayer's funds and the environment itself.

The power could complement regulatory acceptability and toleration of self-insurance provided there was a requirement for operators to hold a specified value of land within the jurisdiction. Despite the risks associated with it, the measure continues to be tolerated by policy makers and environmental regulators. This may be due to the lobbying power of companies large enough to self-insure, the major oil companies being an obvious example. The combination of self-insurance with the regulator's statutory power to take a first-ranking charge would prevent much of the evasive behaviour discussed above. It is for another article to consider the viability and utility of taking charges over 'non-conventional' premises such as oil rigs, vessels, wind farms or long leases of them, but many of the arguments deployed here would be relevant. And other innovative means of preventing operator's externalising their environmental liabilities upon insolvency must be explored.

During UK Parliament debates which considered the prospect of introducing a statutory charge for environmental liabilities in Scotland it was asserted that: 'The Government believe that the existing mechanisms under Scots law for recovering costs are adequate, but we are prepared to review that'. ${ }^{152}$ We contend that the time has come for the position to be reviewed and for the regulatory utility of the environmental charge in Scotland finally to be realised.

\section{ACKNOWLEDGEMENTS}

The authors are grateful to Valerie Fogleman, Joanne Hawkins, Andrew Keay, Gerry McCormack, Duncan Sheehan, Andrew Steven and Donna McKenzie Skene, together with

\footnotetext{
152 HC Deb 28 June 1995, vol 262, col 959 (Sir Paul Beresford MP) (emphasis added).
} 
the editor and two anonymous reviewers, for valuable comments on earlier drafts of this article. Any errors, of course, remain those of the authors. Malcolm Combe would also like to acknowledge the Carnegie Trust for the Universities of Scotland who provided support during the period of research leave in which this article was written. 